\title{
A SZIMBIOTIKUS EMBERTŐL AZ EGZISZTENCIÁLISAN FOGYATÉKOS EMBERIG $^{+}$
}

\author{
FARKAS JÁCINT \\ Budapesti Corvinus Egyetem \\ Szociológia és Kommunikációtudomány Doktori Iskola
}

\begin{abstract}
A folyamatban lévő kutatás a fogyatékosság és az akadálymentesség közismert fogalomtársításait egy többdimenziós filozófiai hálóba szőve, a tér, a lét és az idő minden irányába igyekszik kiterjeszteni és neutralizálni. Mindezt azért tartjuk fontosnak és a társadalmunkra nézve hasznosnak, mert a tudományos és a köznapi diskurzusokban használva, a fenti fogalompárhoz kapcsolódó értelmezési módok, az esetek túlnyomó többségében, negatív konnotációt kapnak.
\end{abstract}

Kulcsszavak: akadálymentesség, funkcionális és egzisztenciális fogyatékosság, szimbiotikus ember

This paper extends and neutralizes the widely-known connotations of disability and accessibility towards all the directions of space, existence and time. This is considered as important and useful for our society because the interpretations related to these terms carry negative implications in the majority of cases in scientific and everyday discourses.

Keywords: accessibility, functional and existential disability, symbiotic human

\section{Bevezetés}

$\mathrm{J}$

elen tanulmány a fogyatékosság és az akadálymentesség jelentésvilágának életbölcseleti, hermeneutikai és antropológiai-filozófiai vizsgálatát tüzi ki célul. A tanulmány tehát a filozófiai értelmezési módok széles skáláját veszi górcső alá: a vizsgálódás spektruma a buddhista filozófia kiemelkedő alakjától, Nágár-

Levelező szerző: Farkas Jácint, 1048 Budapest Lóverseny tér 6. E-mail: farkas.jacint@gmail.com

+ Jelen tanulmány az Európai Unió, Magyarország és az Európai Szociális Alap társfinanszírozása által biztosított forrásból az EFOP-3.6.3-VEKOP-16-2017-00007 azonosítószámú „Tehetségből fiatal kutató - A kutatói életpályát támogató tevékenységek a felsőoktatásban” című projekt keretében jött létre. 
dzsunától ${ }^{1}$ egészen a huszadik század meghatározó nyugati gondolkodóiig (például Karl Jaspers, Martin Heidegger, Hans-Georg Gadamer, Henri Bergson, Peter Kropotkin, Polányi Károly) terjed.

A vizsgálódás filoszkóp jellegü, ami egyrészt utal a meglévő ismeretek felhasználására, azok új kontextusba helyezésére és új kapcsolódási pontok létrejövetelére, másrészt pedig a gondolkodás és ezzel szoros összefüggésben a fogalmak újraértelmezésére, az alkotás folyamatjellegére, és mindezek újra- és újrafelfedezésére is ráirányítja a figyelmet.

A téma vizsgálatához sajátos kutatásmódszertan szükséges, mely - a teljesség igénye nélkül - elsősorban a Gadamer (2003) nevéhez füződő filozófiai-hermeneutikai vizsgálódás ${ }^{2}$ újragondolt alkalmazásán, továbbá a Jaspers (1990) által kidolgozott egzisztenciális analitika, illetőleg a Nágárdzsuna (Fehér 1997) által kidolgozott ürességfilozófia dialógusra épülö, bölcseleti feltáró elemzés „fúzióján” alapul. Röviden ez a következők szerint írható le: a fogalmak jelentéstartalmának feltárása és az új megközelítések kidolgozása a vonatkozó irodalomban való elmélyülésen túl, a megszerzett ismeretek „organizálása" szóbeli diskurzusok sokaságán, valamint a gyakorlati tapasztalatok szondázásán keresztül kristályosodik ki. Mivel a kutatás bölcseleti centrumú, javarészben elméleti következtetésekre törekszik. Azonban nem nélkülözi természetesen a sajátos empirikus alátámasztást sem, mint az az alábbiakban látható lesz.

Amikor tehát a későbbiekben katedrai próbáról beszélünk, akkor az oktatóként szerzett tapasztalatok, benyomások hermeneutikai és dialogikus elemzésére, értelmezésére gondolunk elsősorban. A szerző mint veleszületetten súlyos mozgássérült az oktatási tevékenysége során, mintegy első kézből tudja érzékelni a hallgatók fogyatékossággal kapcsolatos attitüdjeit és azok változásait. ${ }^{3}$ Ezek a megfigyelések és következtetések empirikusan is igazolhatók. A szemeszterek során a Budapesti Gazdasági Egyetem (BGE) és a Budapesti Corvinus Egyetem (BCE) turisztikai szakirányt választó - alapés mesterképzésben részesülő - hallgatóinak az egyéni (Mező 2019), illetve közösen létrehozott projektmunkáik szövegeiben is, jól követhetően testet öltöttek az említett szemléletmódokban bekövetkezett, pozitív irányú módosulások.

\section{Az egzisztenciális emberképről}

Úgy a tudományok területén, mint a hétköznapokban, az ember gondolkodó mivoltát szoktuk leginkább emlegetni, mint olyan sajátos tulajdonságot, mely öt a bolygónkon élő valamennyi létformától megkülönbözteti. A homo sapiens azonban nem kizárólag

\footnotetext{
Nágárdzsuna, a 2. századi indiai buddhista filozófus a Nálanda-i egyetem egykori apátja, az ürességfilozófia iskola alapítója. A buddhizmusban a második Buddhaként is tisztelik. A „buddhista középút” filozófiájának (madhjamaka) az első mestere. Az ürességtan filozófiai iskolája szerint a dolgok csak egymást feltételezve létezhetnek. Ezért semmi sem áll meg önmagában, a dolgok természete ilyen értelemben az üresség (Fehér 1997).

2 A filozófiai diskurzusokban a vizsgálódás, illetve a kutatás, továbbá a filozófia és a bölcselet kifejezések szinonimaként használatosak.

3 A fogyatékosságok megéléséből származó szakértelem ugyanolyan értékkel bír egy kutatás során, mint az egyéb, a kutatói közösség által elismert eljárások (Heiszer 2015).
} 
gondolkodó lényt jelent, mivel ez a közismert latin elnevezés az embert a természetbe mintegy belekóstoló létezőként is definiálja. ${ }^{4}$

Mi ez utóbbi úton közelítjük meg az ember fogalmát, vagyis egy olyan entitás eredetét kutatjuk, aki amellett, hogy képes gondolkodni, s ezáltal például eszközöket létrehozni a környezetének segítségével, illetőleg annak jelentős átalakításával, sőt az utóbbi évtizedekben annak kizsákmányolásával. Az úgynevezett „belekóstolás” szinte szó szerint értendő ebben az esetben, ezzel kívánjuk jelezni, hogy az ember nem a természet felett álló független létező, nem kifosztja azt, hanem kér és kap is mintákat abból a világból, melynek ő maga is elválaszthatatlan része. Véleményünk remekül körbe írja a Heidegger és a Jaspers által egyaránt megfogalmazott sajátos, ránk jellemző tevékenységet, vagyis azt, ahogyan a létezéshez viszonyul vagy viszonyulhat a homo sapiens (Nyíri 2015: 9., 12.).

Tehát az ember akár sodródik, akár a jelen pillanatban tökéletesen stabil tudattal szemlélődik, egy olyan viszonyban áll a léttel, hogy óhatatlanul részese is annak, vagyis a mintavétel folyamatosan megvalósul.

Vizsgálatunk szempontjából mindezeket azért fontos leszögezni, mert álláspontunk szerint - igazodva a Geblen (1976) által megfogalmazott paradigmához - az ember azért hozza létre a kultúrát és a társadalmat, mert mintegy az élővilág többi szereplöjéhez képest hátrányokkal küzd, s ezen hátrányok leginkább a fizikumának sajátosságaiból (gyengeségeiből) adódnak. Ehhez jól illeszthető Polányi (2004) reciprocitáselmélete is, amennyiben az egymásnak történő segítségnyújtás mint sajátosan emberi tevékenység összekapcsolódik a társadalmiság szükségszerűségével. Mint ahogy Kropotkin (1908) is megállapítja, a kölcsönös segítség mint evolúciós mozgatórugó a saját nemünkre is jellemző tulajdonság. ${ }^{5}$ Mindezekből következően a lét elválaszthatatlan részét képező ember szemléli, alakítja, napjainkra pedig radikálisan átrendezni véli a tőle egyre inkább függetlenként értelmezett létkörnyezetét. ${ }^{6}$

A létkörnyezet alakítása az emberi lények megkerülhetetlen képessége és egyben túlélési záloga is (Horváth 2019). Hogy ez a tevékenység miként válik a későbbiekben az alkalmazkodásból „akadálymentesitéssé", ahhoz fel kell vázolnunk egy olyan emberképet, amely a fent már többször említett létbeli integritásán túl rendelkezik egy megismerési képességéből adódó önreflexív képpel, mely nem más, mint a saját halandósága „időbe vetettségének” felismerése. Jaspers (1996) rendkívül közérthetően úgy fogalmaz az ember világban betöltött helyével kapcsolatosan, hogy bár gondolkodó, és bizonyos mértékben előrelátó, a hétköznapokban ezek a képességek csak részben domborodnak ki. Úgy is fogalmazhatunk, a mindennapi élet sodrása, feladatai stb. következtében mintegy automata üzemmódban élünk, csak az általa határhelyzetnek nevezett szituációkban válik világossá mindannyiunk számára az emberi élet környezetnek való kitettsége, mulandósága, és kétségbeesettsége (Jaspers 1996). A lét egyik „összetevője” tehát

4 Erről bővebben tájékozódhat az olvasó az Antropológia az ember balála után című könyvben, ahol elsősorban implicit módon jelenik meg az ember és a természet közötti viszony azon olvasata, miszerint a homo sapiens nemcsak gondolkodik a környezetéről, hanem abba mintegy „bele is kóstol” (Kamper-Wulf 1998).

5 Csányi Vilmos az evolúciós rendszerekről szóló könyvében, mint tudományosan alátámasztott alternatívát említi az orosz természettudós és filozófus fent idézett evolúciós gondolatmenetét (Csányi 1988).

6 A létkörnyezet és a lét az értelmezésünk és szóhasználatunk szerint ekvivalens fogalmak, csupán az akadálymentesség és akadálymentesítés közötti jelentős értelmezési különbségre igyekszünk ezzel a „fogalompárral" ráirányítani a figyelmet. 
az ember, aki egy rendkívül komplex lény, rendkívüli lehetőségekkel, de legalább ennyi egzisztenciális fogyatékossággal is bír. Nietzsche emberideálja az emberfeletti ember éppen arra való reflektációként is értelmezhető, hogy ez a rendkívüli összetettség és egymásnak látszólag szembefeszülő potencialitás-aktualitás feszültség hogyan oldható fel számunkra (Nietzsche 2000).

Itt kényszerűen elérkezünk az ember értékeléséhez, ami rendkívüli óvatosságot követel meg részünkről. A körültekintés legfőbb oka nem elsősorban valamiféle félelem a lehetséges félreértésektől, mint inkább annak a szándéka, hogy minden olvasó és érdeklődő számára világossá váljon, sem negatív, sem pozitív értelemben nem kívánjuk megváltoztatni a kialakult emberképeket. A fent említett filoszkóp módszert segítségül hívva egy újonnan összeálló szinskálával igyekszünk gazdagítani az emberi nemről ez idáig kialakított jelentésvilágokat. Bízunk benne, hogy ezáltal új lehetőségek nyílhatnak meg akár a tudományos, akár a hétköznapi diskurzusokban a fogyatékosság és az akadálymentesség fogalmi dimenzióiba történő betekintésre.

A heideggeri létfelejtés és annak elfelejtéséről írt gondolatok (Heidegger 2019) elemzése nyomán jutottunk el arra a megállapításra, hogy jelen korunkban kialakult az úgynevezett emberségfelejtés állapota. Ez a mi emberképünk szempontjából azt jelenti, hogy megítélésünk szerint az emberben a többi létezőtől alapvetően megkülönböztető, elemző és alkalmazkodó képességei esetében jelentős deficit alakult ki. Elsősorban a felvilágosodás és az ipari forradalom hatásaira kialakult individuális szemlélet mintegy szétfeszítette, napjainkra pedig atomizálni látszik azokat az emberi létezést meghatározó, és véleményünk szerint egyáltalán lehetővé tevő fundamentumokat, melyek kötőanyaga az emberek közötti összetartás magától értetődő mivoltában keresendő (Han 2019). $\mathrm{A} z$ emberi nemre - ahogy annak valamennyi létezésbeli társára, így a növényekre és az állatokra is jellemző egyedi vonásokra, tulajdonságokra - úgy tekint, az egyén a fent említett mesterséges elkülönülése következtében, mint valamiféle fogyatékosságra. Az individuum mára önmagát is feledni látszik, igyekezve megfelelni a technikai civilizációra jellemző termelési és fogyasztási kényszernek, amely a külvilág tárgyainak, eszközeinek és nem utolsósorban az egészséget garantáló és lehetővé tevő szerek birtoklásának soha meg nem szünő ingerlésével tartja sakkban az egzisztenciálisan fogyatékossá vált embert (Fromm 2012).

$\mathrm{A} z$ ember élettani értelemben nem tud nem ember lenni, de meglátásunk szerint a létezése képes olyan mértékben leegyszerüsödni, ami a fentiekben említett létfelejtésnek egy olyan dimenziója, amelyben az ember már elfelejti a jaspersi határhelyzet felismerőképességét is (Jaspers 1996, 2008). Buddhista terminológiával élve az élet ki nem elégítő voltát (p.: dukkha) még nagy vonalakban sem képes érzékelni az ember (Porosz 2012). Éppen ezért, kevés kivételtől eltekintve, a létezés és a közte kialakult hasadásra - ami a saját értelmezésünkben, Jaspers (2008) nyomán, hasítást jelent, amit maga az ember hoz létre folyamatosan - mint természetes állapotra tekint az individuum (Rábula 2014: 143-148.).

Úgy látjuk tehát, hogy az emberi lények nagy családja folyamatosan elfeledi és elengedi azt a lehetőséget, ami jelen tudásunk szerint a földön őt egyedüliként jellemzi, vagyis a másság felismerésében és kiaknázásában rejlő lehetőségeket. Abba a hitbe ringatja magát, hogy a természet és így a létezés urává is vált az elmúlt szük két évszázad során. Nietzsche (2003) ezt úgy látja, hogy a saját maga által elkövetett istengyilkosság áldozatává vált. Ezt úgy értelmezzük, hogy az ember elveszíti a saját magában rejlő 
szellemi képességek felhasználási lehetőségét, vagyis azt, hogy a létezés részeseként önmagát és ezzel a saját maga által alkotott közösségeket is jobbá tegye. Így az emberi szellem forrásvidékétől folyamatosan eltávolodik, holott az nem a távoli múltban vagy a még be sem következett jövőben található, hanem éppen a jelen pillanatokban.

Álláspontunk szerint az a buddhista meditáció (szatipatthána), amelynek alkalmazása által Sákjamuni Buddha elérte a megvilágosodást, éppen a tudatos jelenlétnek a gyakorlata. Vagyis a Buddha azzal érte el a megszabadulást, hogy meg tudott maradni az itt és mostban, és nem szükítette be, nem akadályozta a tudatát az elégedetlenség, így akadálytalanul láthatta a jelenségek közötti okok és feltételek rendszerét, amelyet a kölcsönös függésben való keletkezésként (pratítja szamutpáda) írt le, amit Nágárdzsuna az ürességgel azonosít ${ }^{7}$ (Garfield 1994).

\section{A forrásvidék szimbiotikus emberétől az akadályai rabjává váló, egzisztenciálisan fogyatékos emberig}

Csatlakozunk Jaspers (2000) gondolataihoz, mely szerint a bölcselet útján járó embernek nem annyira a kategorikus kijelentés és igazság megfogalmazására kell törekednie, mint inkább a létező és a létezés között folyvást felmerülő kérdéseket kell kutatnia, s benne önmagát is - újra meg újra - megfogalmaznia az emberi nyelv igencsak korlátozott módján.

Heidegger $(1994,2019)$ munkássága során többször szisztematikusan megfogalmazza azon álláspontját, miszerint a modern ember az elmúlt évezredek során egyre inkább eltávolodik az általa eredetnek nevezett állapottól. Ez nem egy földrajzi koordinátát vagy az univerzum valamelyik konkrét pontját jelenti, hanem azt az emberi szellem által elérhető állapotot, amelyből például a preszókratikus filozófusok szemlélték a létet mint létezőt. Tehát ekkor még az ember úgy alkotta meg a körülötte lévő világról a leírását és az ezt megjelenítő magyarázó fogalmait, hogy a létezés természetéből indult ki, aminek önmaga is szimbiotikus része volt. Jaspers, Bergson, Kropotkin, Nietzsche és Nágárdzsuna meglátásunk szerint - hasonlóan Heideggerhez és Gadamerhez - ezt a módszert alkalmazta a saját bölcseleti fogalomrendszerének megalkotása során.

A kutató- és alkotómunka során megértettük ezen eredet feltárására irányuló filozófia jelentőségét és rendkívüli erejét a fogyatékosság és az akadálymentesség át- és újraértelmezésének viszonylatában. A két általánosságban használt fogalomra oly sok sztereotip és tudományos determinációs réteg rakódott és rakódik folyamatosan, amelyek álláspontunk szerint egyesével, de különösen összességükben akadályozzák az értelmezési és szellemi vizsgálódást.

Bergson intuitív filozófiai módszertana (Deleuze 2010) véleményünk szerint nemcsak azért kevésbé használatos vizsgálódási mód még a szakbölcseleti körökben is, mert az intuícióhoz legalább annyi félreértés tapad(hat), mint a jaspersi transzcendenciához (Jaspers 2005), vagy az általunk vizsgált fogyatékossághoz, hanem azért is, mert az életbe való belemerülés értelmezésünk szerint éppen a heideggeri eredet állapotba történő

Jaspers egzisztáló embere is hasonló: éber tudatállapotban és a jelen pillanatában időzik. Ennek a fenntartásához a német bölcselő szerint állandó koncentrációra van szükség (Jaspers 2005). 
újra bejutást jelenti, amely empirikusan, de még az ismeretelmélet górcsövével sem igazolható, vizsgálható. ${ }^{8}$

Jaspers (1992, 1998) gondolatvilágát megismerve arra a következtetésre jutottunk, hogy az általa határhelyzetnek nevezett szituációk - súlyos betegség, egy hozzátartozó

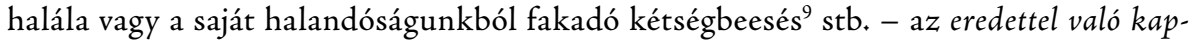
csolatba kerülésnek is tekinthetők, és ami ennél is fontosabb, megélhetők az eredettel való kapcsolatba kerülésként. Jaspers (2008) másik, témánk szempontjából kiemelendő originális - de az előzőekkel szorosan összefüggő - saját fogalma a tengelykor. Ez egy olyan történeti periódust ölel fel, amelyben például Európában Szókratész, Indiában pedig a Buddha lépett ki az emberiség szellemi szinpadára, és onnan adta máig is érvényes szóbeli tanításait. Úgy tekintünk a jaspersi tengelykor végére, mint a fentebb említett emberségfelejtéshez és az ezzel szoros összefüggésben álló - mára mindannyiunkat egyaránt jellemző - egzisztenciális fogyatékossághoz vezető út elejére.

\section{A katedra mint a fogalmi kiterjesztéseink bergsoni és jaspersi próbája}

Úgy gondoljuk, hogy feltétlenül szót kell ejtenünk a vizsgálódásaink során szerzett gyakorlati jellegü oktatási tapasztalatainkról, amelyek java része az utazás világának alap- és mesterszintű szakemberképzéséből származik. Mint már a bevezetőben utaltunk rá, a Budapesti Gazdasági Egyetem és a Budapesti Corvinus Egyetem turisztikai szakirányain hallgatók oktatásában van, illetve volt módunk részt venni. Ennek kapcsán a funkcionális fogyatékosság általunk klasszikusnak nevezett megközelítési módjaiból indulunk ki, nevezetesen abból, hogy az emberek gondolkodásában az akadálymentesítés fogalmához elsősorban a fizikai életkörnyezet átalakítása társul. ${ }^{10}$

A $z$ akadálymentesítés fogalomkörének társadalmi beágyazottságát - és a klasszikus megközelítés egyeduralmát - jól jellemzi, hogy a tevékenységet az emberek közel 100 százaléka a fizikai életkörnyezetünk átalakításával, illetve annak szükségszerűségével azonosítja (Farkas 2019). Ami még ennél is érdekesebb számunkra, hogy a legtöbb esetben a mobilitás, közlekedés, tehát a mozgás akadályainak elhárításaként azonosítja azt a társadalom. Nincs ez másképp az utazás világában sem, igaz, erre vonatkozó empirikus kutatást nem végeztünk az elmúlt közel három év oktatói gyakorlata során. Ugyanakkor a különböző felsőoktatási intézményekben szerzett tapasztalataink alapján viszszaköszönni láttuk és látjuk a mai napig is Szauer és munkatársai (2010) megállapításait,

\footnotetext{
Sajnálatos módon a tanulmány terjedelmi keretei nem teszik lehetővé a jelzett vizsgálhatósági nehézség feloldása érdekében tett erőfeszítéseink bővebb kifejtését, így például a hermeneutikai gömb és a filoszkópikus vizsgálódás elnevezésű ismeretszerzési, bővítési módszerünk részletesebb tárgyalását. Ezekről mintegy kedvcsinálóként annyit tudunk itt jelezni, hogy véleményünk szerint a filoszkópikus vizsgálódás és a töredezettségmentes hermeneutikai gömb szemlélet alkalmazhatóságának egyik alapfeltétele a kutatóiindividuum időleges feladása az ún. metaviduum állapotba történő beleoldódásért „cserében”. Tehát véleményünk szerint az eredet vidékére történő el-, illetve bejutásnak ma is életre hívhatóak a feltételei.

9 Vö. Kierkegaard (1986).

10 Értelmezésünk szerint - melyben természetesen szerepet játszik az a speciális élethelyzet, melynek következtében a tanulmány írója a már említett mozgásfogyatékossága révén jár-kel a hétköznapokban - a semmit rólunk nélkülünk elve nem kizárólag a döntéshozatalok során kell, hogy érvényesüljön, hanem az élet valamennyi területére kiterjeszthető. Éppen ezért inkább ezt úgy nevezzük, hogy amit csak lebet, közösen valósitsuk meg.
} 
mely szerint a fogyatékosság értelmezése mennyire összeforrott az akadálymentesítés gyakorlatával, illetve annak elveivel. A fentebb említett, a hallgatók által készített dolgozatok, projektanyagok és a Mező (2019) által készített szakdolgozat ${ }^{11}$ és az ahhoz kapcsolódó empirikus kutatások egyértelműen alátámasztják a fogalompár „automatikus” együtt értelmezésének tényszerüségét.

Összességében kijelenthető, hogy a hallgatóság nyitottabban áll a fogyatékosság kérdéséhez, ha az manifeszt módon megjelenik számára - azaz például mikor funkcionálisan fogyatékos oktatóval kerülnek kapcsolatba -, továbbá, ha a kérdésről egy sokkal szélesebb spektrumú képet tudunk felvázolni.

Kutatásunk során lehetőségünk nyílt arra is, hogy az általunk alkotott új fogalmakat és a hozzájuk kapcsolódó szemléletváltó tartalmakat „teszteljük”. Ezeket körbejárva, kívülről szemlélve, majd beléjük ereszkedve. ${ }^{12}$ Azt tudjuk biztosan kijelenteni, hogy a hallgatók például a projekttervezési feladatok megvalósítása során, rendkívül rugalmasan és nyitottan kezelték a fogalmi spektrumbővítéseket és az ebből következő vizsgálódási módokat, amint ezt az elkészült projektdokumentációk és a beszámolók részét képező prezentációk egyértelműen alátámasztják.

\section{IRODALOM}

Bergson, H. (2012) A gondolkodás és a mozgó. - Esszék és elöadások. Budapest, L'Harmattan Kiadó.

Csányi V. (1988) Evolúciós rendszerek. - Az evolúció általános elmélete. Budapest, Gondolat Könyvkiadó.

Deleuze, G. (2010) A bergsoni filozófia. Budapest, Atlantisz Könyvkiadó Kft.

FARKAS J. (2019) Az akadálymentesítés primátusa a turisztikai termékfejlesztésben. In: Irimiás A., Jászberény M. \& Michalkó G. (eds) Innovatív turisztikai termékfejlesztés. Budapest, Akadémiai Kiadó. pp. 146-157.

Fenér J. (1997) Nágárdzsuna, a mahájána buddhizmus mestere. Budapest, Farkas Lőrinc Imre Könyvkiadó.

Fromm, E. (2012) A szeretet müvészete. Budapest, Háttér Kiadó.

Gadamer, H-G. (2003) Igazság és módszer. Budapest, Osiris Kiadó.

Garfield, J. (1994) Dependent Arising and Emptiness of Emptiness: Why Did Nagarjuna Start with Causation. Philosophy East and West, Vol. 44. No. 2. pp. 219-250.

Gehlen, A. (1976) Az ember. Budapest, Gondolat Könyvkiadó.

Han, B-C. (2019) A kiégés társadalma. Budapest, Typotex Elektronikus Kiadó.

Heidegger, M. (1994) „....Költöien lakozik az ember...” Budapest, T-Twins Kiadó.

Heidegger, M. (2019) Lét és idő. Budapest, Osiris Kiadó.

Heiszer K. (2015) Participatív kutatás, intellektuális sérülés. In: Hernádi I. \& KönCzei Gr. (eds) A felelet kérdései között. Fogyatékosságtudomány Magyarországon. Budapest, Eötvös Loránd Tudományegyetem Bárczi Gusztáv Gyógypedagógiai Főiskolai Kar. pp. 68-78.

11 A Mező (2019) által készített diplomadolgozat - melynek a jelen tanulmány szerzője társtémavezetője volt - címe magáért beszél: Az információk hozzáférhetőségének centrális jelentősége az akadálymentes turizmusban.

12 Erről lásd: Bergson (2012) és Jaspers (1990). 
Honváth B. (2019) A beteg bolygó. A fenntarthatatlanság és a betegség kultúrtörténete. Budapest, Typotex Kiadó.

Jaspers, K. (1990) Az egyetem eszméje. Ész, Élet, Egzisztencia, Vol. 1. pp. 177-274.

Jaspers, K. (1992) Ész és egzisztencia. Ész, Élet, Egzisztencia, Vol. 2-3. pp. 343-430.

JASPERs, K. (1996) Bevezetés a filozófiába. Budapest, Európa Kiadó.

Jaspers, K. (1998) Filozófiai önéletrajz. Budapest, Osiris Kiadó.

Jaspers, K. (2000) A filozófiai gondolkodás alapgyakorlatai. Budapest, Farkas Lőrinc Imre Könyvkiadó.

Jaspers, K. (2005) A transzcendencia rejtjelei. Budapest, Kairosz Könyvkiadó Kft.

JAspers, K. (2008) Mi az ember? Filozófiai gondolkodás mindenkinek. Budapest, Media Nova $\mathrm{Kft}$.

Kamper, D. \& Wulf, C. (1998) Antropológiai az ember halála után. Budapest, Jószöveg Mühely Kiadó.

KierkegaArd, S. (1986) Félelem és reszketés. Budapest, Európa Könyvkiadó.

Kropotrin, A. P. (1908) A kölcsönös segitség, mint természettörvény. Budapest, Athenaeum Könyvkiadó.

Mező, N. (2019) Az információk hozzáférhetőségének centrális jelentősége az akadálymentes turizmusban. Szakdolgozat. Budapest, BGE KVIK.

Nietzsche, F. (2000) Így szólott Zarathustra. Budapest, Osiris Kiadó.

Nietzsche, F. (2003) Ecce homo. Hogyan lesz az ember azzá, ami. Budapest, Göncöl Kiadó.

Nyíri T. (2015) Antropológiai vázlatok. Budapest, Corvinus Kiadó.

Polány K. (2004) A nagy átalakulás. - Korunk gazdasági és politikai gyökerei. Budapest, Napvilág Kiadó Kft.

Porosz T. (2012) A buddhizmus lexikona. Budapest, A Tan Kapuja Buddhista Főiskola.

Ráhula, V. (2014) A Buddha tanitása. Budapest, A Tan Kapuja Buddhista Föiskola.

Szauer Cs., Fehér I., Gombrötő A., Lakatos P., Nagy Zs. A., Páter T., Perjés B., Schüttler T., Simonics B. \& Szentikatolnay M. (2010) Képzés és komplex rehabilitáció a fogyatékos emberek társadalmi integrációjának támogatásáért. Új Pedagógiai Szemle, Vol. 60. Nos 10-11-12. pp. 69-101.

A cikk a Creative Commons Attribution 4.0 International License (https://creativecommons.org/licenses/ by/4.0/) feltételei szerint publikált Open Access közlemény, melynek szellemében a cikk bármilyen médiumban szabadon felhasználható, megosztható és újraközölhető, feltéve, hogy az eredeti szerző és a közlés helye, illetve a CC License linkje és az esetlegesen végrehajtott módosítások feltüntetésre kerülnek. (SID_1) 